\title{
INSTITUTIONAL LEVERS FOR FINANCING SMALL AND MEDIUM-SIZED BUSINESSES AS A COMPONENT OF DEVELOPMENT OF DEPRESSED REGIONS
}

\author{
L. V. Tymoshenko, Ph. D (Econ.), Associate Professor, Dnipro University of Technology, \\ timoshenkolv@ukr.net,orcid.org 10000-0003-4869-8244 \\ O. V. Krylova, Ph. D (Tech.), Associate Professor, Dnipro University of Technology, \\ krulo-ov@i.ua, orcid.org 10000-0002-4210-5068
}

Methods. The results were obtained through the application of the following methods: critical analysis - when establishing barriers that impede the effective state support of small and mediumsized businesses at the regional level; scientific abstraction - in determining the advantages of small and medium-sized enterprises in comparison with large business in forming the socio-economic basis for the development of a region (territory, city); generalization - in establishing institutional levers to overcome the territory's depressiveness.

Results. It was diagnosed that the vast majority of business entities in the business sector in Ukraine are small and medium-sized enterprises, which is consistent with global trends. However, the effectiveness of their functioning indicates the presence of obstacles to the use of advantages and potential opportunities. It is shown that financial government support for small and mediumsized businesses is based on legislation and is carried out in direct and indirect forms. The implementation of the state regional policy to stimulate the development of regions and to overcome the territory's depressiveness is determined by a set of legislative acts and state programs. The scientific approaches to the definition of depressed territories and the formation of their varieties are analyzed, the basic principles on which state support for these regions should be based are identified.

Novelty. It is established that the institutional levers and tools to overcome the territory's depressiveness should take into account the regional (local) aspect of the opportunities for realizing the entrepreneurial potential of small and medium-sized businesses, subject to their financial support.

Practical value. The guidelines for the formation of a program for overcoming the city's depression, subject to the interaction of government, business and society, which will allow achieving the goal of developing small and medium-sized businesses, provide comfortable and safe conditions for the population, the formation of a city of social responsibility and social innovation.

Keywords: small and medium business, financial development, institutional support, regional level, depressed territories.

Introduction. Under current conditions, an essential element of a market system and competitive economy involves small and medium-sized businesses (SMBs), without which neither regional economy, in particular, nor the national economy, in general, can function or develop. Therefore, small and medium-sized entrepreneurship is one of the techniques for balancing certain territories, overcoming their depression through creating additional employment, reducing unemployment, saturating the regional market with goods and services, catalyzing economic innovations and develop- ing competition. Ensuring harmonious conditions for the development of business environment involves the formation of an institutional basis, creation and development of an efficient system of the state financial support.

Analysis of the recent research and publications. Flexibility and adaptability to changing external conditions, innovative approach to economy management, willingness to take reasonable risk, commitment to achieving economic and social results of small and medium-sized businesses in today's real life are the key to overcoming crisis phenomena, forming

(C) 2020. L.V. Tymoshenko, O. V. Krylova. Published by Dnipro University of Technology on behalf of Economics bulletin of the National Mining University. This is an Open Access article distributed under the terms of the Creative Commons Attribution License (http: // creativecommons.org/licenses/by/4,0/), which permits unrestricted reuse, distribution and reproduction in any medium provided the original work is property cited 
and developing competitive advantages of the region's.

Small and medium-sized entrepreneurship experiences certain difficulties on its way of efficient development. Studying old industrial regions, V. V. Dotofiienko and V. V. Loskutova [1] focus on one of the obstacles, namely, on underdevelopment of the institutional environment, which can be explained by a high level of corruption and administrative barriers, an insufficient legal and regulatory framework, underdeveloped infrastructure and many other reasons.

O. V. Yakusheva [2] has developed the directions of support of small and mediumsized businesses in the conditions of transformational changes at the regional level, as well as defined the role and place of business incubation within SMB development.

According to L. Ye. Simkiv and S. A. Pobihun [3], formation of the basic directions of enhancing the efficiency of small business functioning at the regional level should be based on taking into account the interests of the territorial community, regional and local selfgovernment bodies, business structures, i.e. all economic entities located within the region.

Thus, scientists focus on the significant role of small and medium-sized entrepreneurship when overcoming imbalances and ensuring the development of individual regions, which requires a systematic and purposeful state policy, aimed at stimulating financial institutions to invest in small and medium-sized businesses.
Purpose of the article. The purpose of the work is to define the theoretical and methodological foundations of forming the institutional levers of financial support for small and medium-sized enterprises for the development of territories which have acquired signs of depression.

Presentation of the main research. The place and role of small and medium-sized entrepreneurship are determined by the quantitative indicators of its activity in Ukraine. The vast majority of Ukrainian companies in the business sector are small and medium-sized enterprises, which is similar to most countries in the world. According to statistics in 2018, the total number of enterprises made 355,952 units. Only $0.1 \%$ (446 units) involves large enterprises, $4.5 \%$ (16,124 units) - middle-sized ones, while the rest, i.e. the vast majority, 95.4\% (339,382 units) - small ones (among them micro-enterprises make 292,783 units or $82.3 \%)$.

Fig. 1 shows the dynamics of the number of medium-sized and small enterprises over the period of 2010-2018. There is a general downward trend in the number of medium-sized business entities (from 20,983 to 16,124 units). The dynamics of the number of small business is characterized by growth in $2013(373,809$ units) followed by a decrease to the minimum value in 2016 (291,154 units) and a further increase in 2018 (339,382 units).

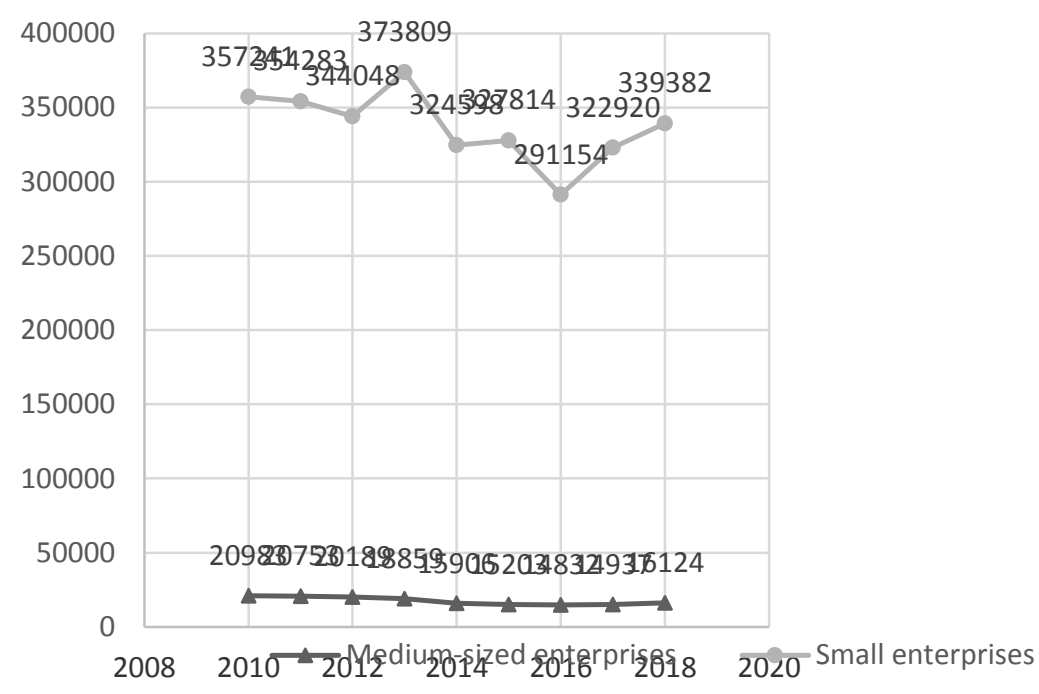

Fig. 1. Dynamics of the number of medium and small enterprises in 2010-2018 
The general downward trend is characteristic of the dynamics of the number of employed workers at the medium-sized and small enterprises during 2010-2018 (Fig. 2). All in all, over the period under study the number of sole proprietors (SPs) of small business decreased (from 2,794 to 2,532.7 thousand people), while the number for medium-sized business, on the contrary, increased (from 20.5 to 40.3 thousand people) (Fig. 3).

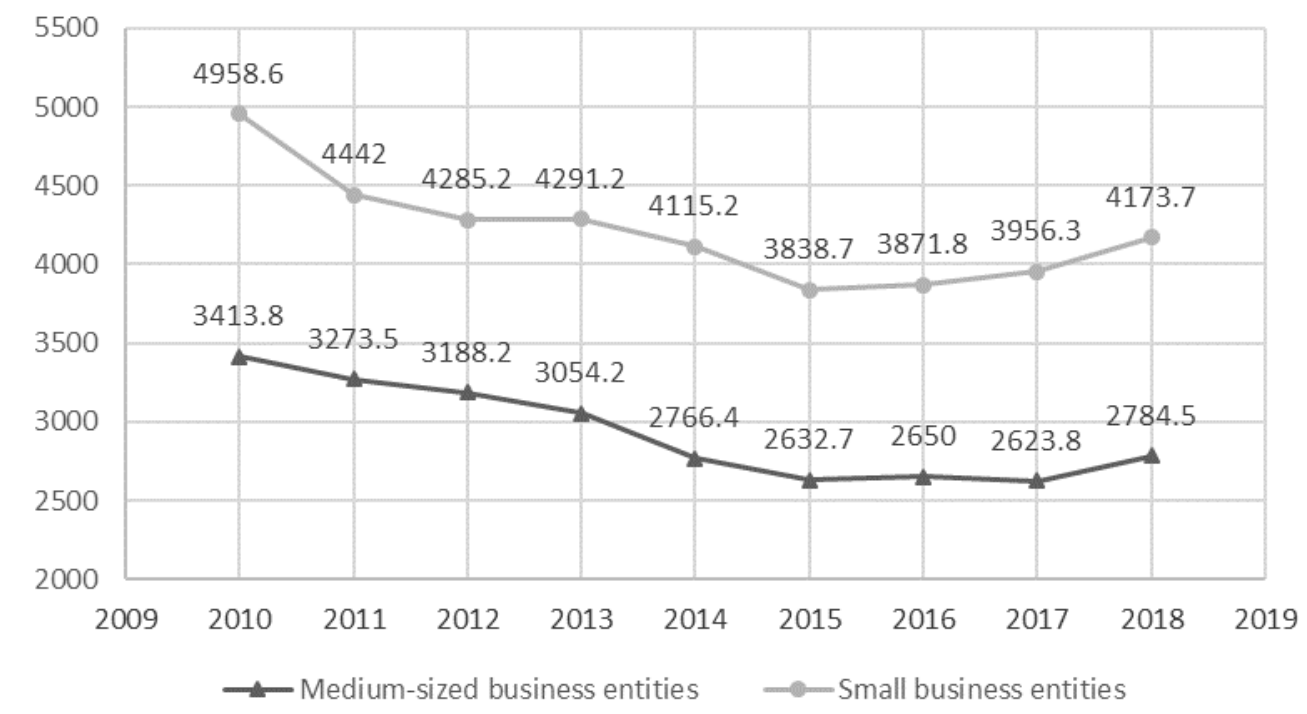

Fig. 2. Business employment dynamics for medium-sized and small business entities in 2010-2018

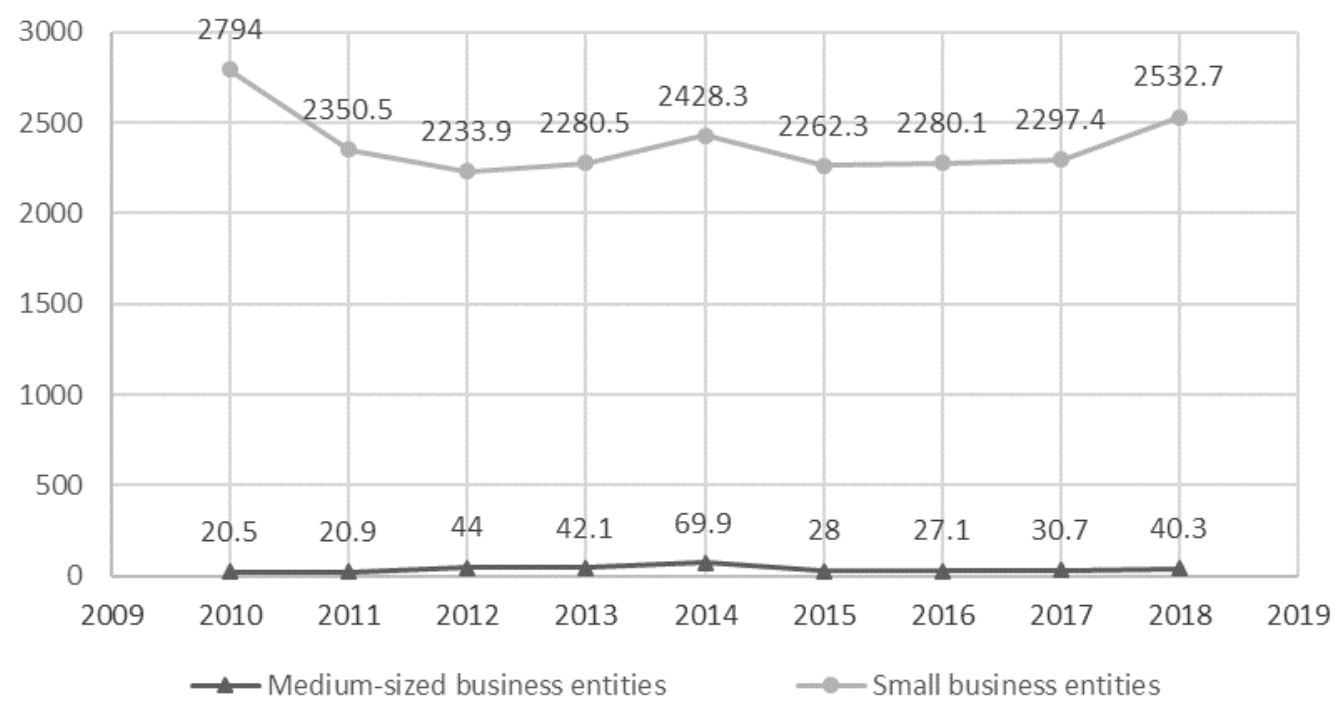

Fig. 3. Dynamics of the number of sole proprietors (SPs) of medium and small businesses in 20102018, thousand people

The analysis of the dynamics of financial results before taxation of medium-sized and small enterprises in Ukraine (Fig. 4) allowed establishing the following: the negative value of small businesses' financial results is observed throughout 2010-2017, that of mediumsized businesses - during 2014-2015; the worst financial results of both small and medium- sized business organisations' management is recorded in $2014(-199,180.3$ and $-175,262.4$ million, UAH, respectively). In 2018, a positive financial result is obtained both by medium (151,479 million, UAH), and small enterprises (46,726.2 million, UAH). 


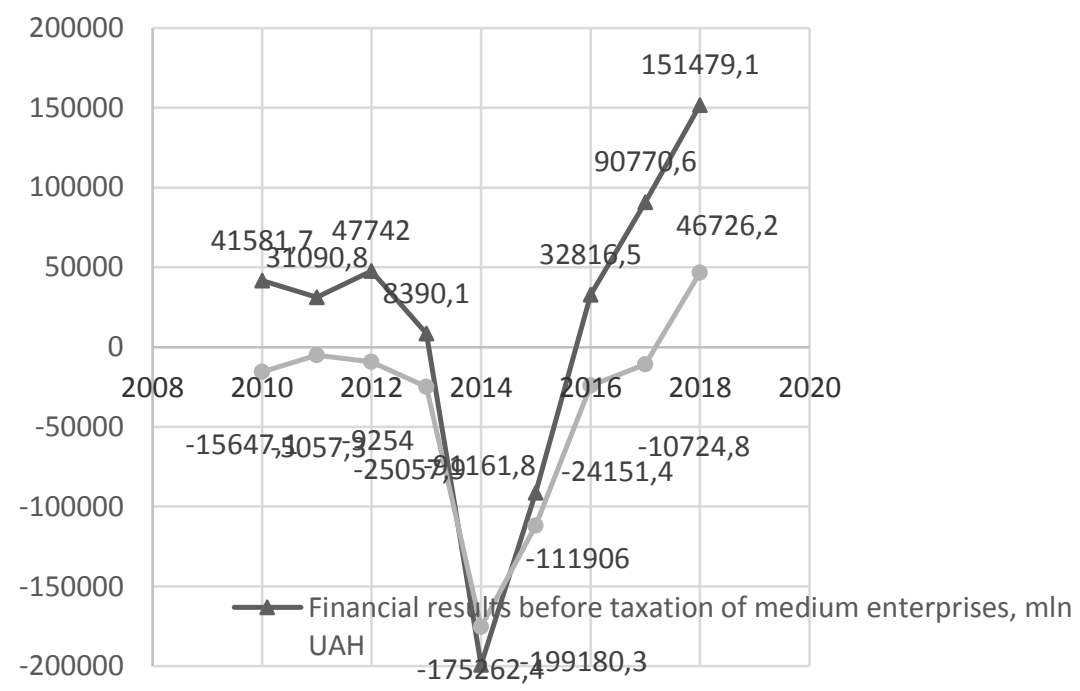

Fig. 4. Dynamics of financial results before taxation of medium and small enterprises in Ukraine

Small and medium-sized businesses were the first to fill a niche of economic activity, focused on regional and local needs as much as possible. In developed countries, sustainable development of the region as well as high quality of life are achieved through establishing a system that is maximally oriented to the efficient use of available regional resources [4].
Therefore, in the context of the decentralization of the Ukrainian economy, it is necessary to consider the peculiarities and role of SMBs in development of the territories.

Compared to big business, the SMBs have certain advantages (Tab. 1), which forms the socio-economic basis for the development of the region (territory, city) and provides for improving the living standards the population.

Table 1

Advantages of SMBs compared to the big business (regional aspect)

\begin{tabular}{|l|l|}
\hline \multicolumn{1}{|c|}{ Advantages } & \multicolumn{1}{|c|}{ Importance for the region } \\
\hline $\begin{array}{l}\text { The SMB operation does not require significant investment, } \\
\text { and capital investments are characterized by rapid time to value }\end{array}$ & $\begin{array}{l}\text { Simplified setting up of a business, filling of a busi- } \\
\text { ness segment in the region }\end{array}$ \\
\hline $\begin{array}{l}\text { The SMB is characterised by the capacity for dynamic and } \\
\text { prompt development, the necessary mobility in the market, } \\
\text { commitment to innovation, prompt response to consumer needs }\end{array}$ & $\begin{array}{l}\text { Generating new ideas, implementing them in the re- } \\
\text { gional market, taking into account the needs of a } \\
\text { small number of their customers }\end{array}$ \\
\hline $\begin{array}{l}\text { Openness of access and ease of entry into SMBs increases the } \\
\text { possibility to engage professionals who are willing to take risks } \\
\text { and work for a small salary }\end{array}$ & $\begin{array}{l}\text { Increasing the independence and confidence of the } \\
\text { entrepreneur to generation of new ideas, reducing the } \\
\text { cost of creating jobs }\end{array}$ \\
\hline $\begin{array}{l}\text { SMBs significantly increase market competition and encourage } \\
\text { entrepreneurs to operate more efficiently and to higher stand- } \\
\text { ards }\end{array}$ & $\begin{array}{l}\text { SMBs are better at providing local markets with } \\
\text { goods and services, while big business is slowly de- } \\
\text { veloping a market in each region }\end{array}$ \\
\hline $\begin{array}{l}\text { SMBs employ workers fired during restructuring of large enter- } \\
\text { prises, create opportunities for the formation of the middle } \\
\text { class, whose existence weakens the tendency of social differen- } \\
\text { tiation specific for a market economy }\end{array}$ & $\begin{array}{l}\text { SMBs solve employment problems in the region } \\
\text { through job creation. }\end{array}$ \\
\hline $\begin{array}{l}\text { SMBs have high mobility in resource utilization, short duration } \\
\text { of reformatting their activities }\end{array}$ & $\begin{array}{l}\text { SMBs increase the level of competitiveness of re- } \\
\text { gions }\end{array}$ \\
\hline $\begin{array}{l}\text { Focusing on providing services in education, healthcare, cul- } \\
\text { ture, and others accelerates active extension of standards of } \\
\text { socialization of the economy }\end{array}$ & $\begin{array}{l}\text { SMBs solve a considerable number of social prob- } \\
\text { lems and those of the social facilities in regional eco- } \\
\text { nomic complexes. }\end{array}$ \\
\hline $\begin{array}{l}\text { SMBs are interested in the economic development of their terri- } \\
\text { tory }\end{array}$ & $\begin{array}{l}\text { SMBs are a significant source of replenishing the } \\
\text { local and regional budgets }\end{array}$ \\
\hline
\end{tabular}

Based on [5]

ISSN 2073-9982, Економічний вісник, 2020, №1 
However, despite the advantages of SMBs, possible risks and disadvantages did not allow this segment of the economy to have an effective influence on the economic and sociopolitical development of the country. Among other reasons of this situation, V. V. Mitsa [6] indicates lack of well-balanced state policy on financing or financial and economic stimulation of successful business projects, promotion of facilitating stimulating lending system, imperfection of the tax mechanism, the low level of promotion of small business at the level of regions and cities by the authorities. Therefore, stable functioning of small business is influenced by negative factors that hinder its development.

The research conducted [7] proves that the factors which negatively affect small business development in Ukraine include:

- very small demand for products $(59 \%$ of

the 1,800 respondents interviewed),

- unstable political situation (44\%);

- high taxes (35\%);

$(27 \%)$;

- complex tax administration system

- inflation and frequent changes in legislation (26\%),

- high regulatory pressure and corruption $(23 \%)$;

- war in the East of Ukraine (20\%);

- low credit availability (19\%).

At the same time, attention is drawn to the fact that lack of financing for business development has proved relevant for $44 \%$ of small and medium-sized enterprises in Ukraine, 33\% of medium-sized businesses and $36 \%$ of small ones suffer from the lack of working capital. It was also found that a large number of small businesses in Ukraine have a low level of innovation potential. Therefore, the use of entrepreneurial potential of SMBs to deal with problems of depressed territories requires state support.

The study [8] compared the characteristics of SMB support systems in different countries of the world and in Ukraine, and noted that small business support in the USA is the most developed and integrated. This is related to many years' experience in establishing an SMB support system at the state level.
Having studied the foreign experience of development of business structures, T. V. Honcharuk [9] notes that at the state level, financial assistance is provided through significant tax concession in the initial operating years, loans on preferential terms to business entities focused on innovation, environmental protection and ecological projects operating in backward regions, enterprises of high social significance. Therefore, there is a positive foreign experience of government support for SMBs in financing and tax policy.

In Ukraine, financial support to small and medium-sized enterprises is based and provided on the legislative framework in direct and indirect forms (Tab. 2).

The law on «On Stimulating the Development of Regions» [12] defines the legal, economic and organisational frameworks for the implementation of the state regional policy for stimulating the development of regions and overcoming the depressiveness of territories.

State stimulation of regional development is performed in accordance with the basics of state regional policy, laws on the State Budget of Ukraine, national programs, other laws and acts of the legislation of Ukraine, as well as programs of economic and social development.

The law [12] defines measures to stimulate the development of depressed territories:

- target allocation of state capital investments in the development of industrial, communication and social infrastructures;

- provision of state support, including financial assistance, to small businesses, support for the formation of business development infrastructure such as business centres, business incubators, innovation and consulting centres, venture funds and others;

- aiming international technical assistance to address urgent socio-economic and environmental problems, as well as to implement other major activities;

- promoting public employment, providing targeted funding for retraining and professional development programs, promoting labour migration, improving the social sphere, including housing, health and the environment;

- providing other state support to these territories. 
Table 2

State financial support for small and medium-sized enterprises

\begin{tabular}{|c|c|c|}
\hline \multirow[t]{2}{*}{ Legislative framework } & \multicolumn{2}{|c|}{ State financial support } \\
\hline & direct & indirect \\
\hline $\begin{array}{l}\text { The Law of Ukraine on } \\
\text { "Development of state financial } \\
\text { support for small and medium- } \\
\text { sized enterprises in Ukraine" de- } \\
\text { fines the main directions of state } \\
\text { policy and types of financial state } \\
\text { support }\end{array}$ & $\begin{array}{l}\text { - introduction of government loan } \\
\text { schemes, } \\
\text { - granting of guarantees for obtain- } \\
\text { ing loans, } \\
\text { - partial compensation of interest } \\
\text { rates on loans; } \\
\text { - partial compensation for leasing, } \\
\text { factoring and guarantee payments; } \\
\text { - provision of guarantees and guar- } \\
\text { antee bonds for loans to SMBs; } \\
\text { - granting of loans for starting and } \\
\text { running your own business; } \\
\text { - granting loans for the acquisition } \\
\text { and introduction of new technolo- } \\
\text { gies; } \\
\text { - compensation for development } \\
\text { costs of cooperation between SMBs } \\
\text { and large enterprises. }\end{array}$ & $\begin{array}{l}\text { - improvement and simplification of tax } \\
\text { treatment procedures; } \\
\text { - introduction of a simplified system of } \\
\text { taxation, financial accounting and re- } \\
\text { porting; } \\
\text { - involvement in the implementation of } \\
\text { scientific, technical and socio-economic } \\
\text { programs, the supply of products for } \\
\text { national and regional needs; } \\
\text { - financial support for the implementa- } \\
\text { tion of energy efficient and environmen- } \\
\text { tally friendly technologies }\end{array}$ \\
\hline $\begin{array}{l}\text { The Law of Ukraine on "Govern- } \\
\text { ment assistance to Business Enti- } \\
\text { ties" establishes forms of state aid } \\
\text { implementation }\end{array}$ & $\begin{array}{l}\text { - provision of subsidies, grants, and } \\
\text { awards, } \\
\text { - provision of tax benefits, deferral } \\
\text { or instalment plans for loans, dues } \\
\text { and fees or other mandatory pay- } \\
\text { ments; } \\
\text { - provision of guarantees, loans on } \\
\text { preferential terms, servicing of cred- } \\
\text { its at preferential tariffs; } \\
\text { - an increase in the state's share in } \\
\text { the authorized capital of business } \\
\text { entities or an increase in the value of } \\
\text { the state's share on conditions unac- } \\
\text { ceptable to private investors }\end{array}$ & $\begin{array}{l}\text { - charge-off of debts, including those for } \\
\text { public services, charge-off of penal sanc- } \\
\text { tions, compensation for losses to busi- } \\
\text { ness entities; } \\
\text { - reduction of financial liabilities of } \\
\text { business entities to compulsory state } \\
\text { social insurance funds; } \\
\text { - provision of goods or services at be- } \\
\text { low-market prices or acquisition of } \\
\text { goods or services at above-market pric- } \\
\text { es; } \\
\text { - sale of state-owned property at below- } \\
\text { market prices }\end{array}$ \\
\hline
\end{tabular}

Based on $[10,11]$

The Law «On the Principles of State Regional Policy» [13] provides for distinguishing territories, which require additional stimulation when planning the development of regions which include these territories. V. S. Kolomiychuk [14] was one of the first to study the issue of depressed territories, determining the mechanism of formation, criteria, depth of depression, and others. Ya. V. Shevchuk [15] substantiated the concept of «depressed territorialsocial system», which is interpreted as such a territorial system of one or another hierarchical level, in which trends of socio-economic development have dramatically changed within a relatively short period of time - from upstream to downward, from prosperity to decline.

S. I. Plotnytska [16] distinguishes the following types of depressed territories: rural settlements, administrative districts, urbanized territories, districts and regions; and emphasizes that the most probable differentiating feature of underdeveloped and depressed territories is the time-frame of the formation and spreading of depression. The characteristic features of depressed territories include: acquired depressiveness over a fixed period of time, intense dynamics of growth, large scale, depth of negative phenomena and lack of resource prospects.

A. Tkachuk [17] emphasizes the identification of several types of territories with special needs for development:

1. Territories, which have geographical limitations (such as highlands).

2. Territories where, due to the changing economic situation, the dominant industry has declined (mainly mining villages).

3. Rural areas with low population density (an area which is not inhabited by people, it is essentially hardly controlled by the state and becomes risk-generating). In European coun- 
tries and the USA, they are called territories that have lost the ability self-reproduce and it is almost impossible to stop this trend downwards without the intervention of the state.

4. Frontier regions adjacent to a border with restricted traffic or special regime.

Depending on the type of special needs area, according to the author [17], the toolkit should be quite different. The state can create the infrastructure, but the state cannot create a business where people will work. Therefore, the state can offer businesses some compensation for this: insurance or tax cuts. In this case, a business risks and performs economic activities, arranging the population on the territory.

N. V. Mozhaykina [18] suggests the following generalized definition of depressed territories of the country: these are regions characterized by low socio-economic development indicators, their negative dynamics, imperfect economic structure, low investment activity and the standard of living of the population, which are unable to provide self-reproduction. There are old industrial, agrarian-industrial and producing (central) depressed regions. Distinguishing of depressed regions is an important part of the regional policy, in the development, implementation, organizational and legal support of which the leading role belongs to the state.

To achieve efficiency and to overcome the depression of the territory, the state support of depressed regions should be based on the principles of state policy selectivity, validity of the choice of objects, targeting, localization, legitimacy and mandatory control of state aid; moreover, it should be implemented in relation to the system of plans of social and economic development of the region.

As for the development of the old industrial regions, V. V. Dorofiienko and V. V. Loskutova [1] point to implementing institutional changes to facilitate the development of small and medium-sized enterprises. These changes should include development of the infrastructure to support new businesses; creation of business incubators and industrial parks; simplification of buying and renting property for small businesses; expansion of the microcredit system; reduction in the number of supervising and surveillance activities by lawenforcement authorities.
An important element of the nation-wide development in the medium term, in particular small and medium-sized businesses, is encouraging the development of depressed territories, which can be implemented in the following actions: state capital investments in the production, communication and social infrastructure of depressed territories, formation of new infrastructure objects, international technical assistance to solve problems of depressed areas [19].

The only town in Ukraine which is recognized to be depressed and which can receive the state support is Tokmak (Zaporizhzhia Region). According to the results of monitoring of socio-economic indicators of development of the corresponding territories in 2016, it was found, that the socio-economic indicators of the development of the regional town of Tokmak of Zaporizhzhia Region meet the criteria of depression. The results of the monitoring show that the economic and social sphere of the town has been in a very depressed state over the last ten years, and further socio-economic development of Tokmak requires state support. Tokmak's depressed state is the result of the destruction of the large town-forming enterprise "Pivdendizelmash" [20]. Tokmak has the official standing of a depressed territory, which they were given in accordance with the Resolution of the Cabinet of Ministers from 27.09.2017 until 2021. This means that Tokmak's unemployment rate is higher than the national average.

The analysis of the local economic structure revealed that more than $66 \%$ of Tokmak's natural and legal persons are inactive [21]. 2,291 business entities are considered, of which 606 are legal entities (representing $26.5 \%$ of the total number of payers) and 1,685 are registered as natural persons - entrepreneurs (accounting for $73.5 \%$ of the total number of payers). The largest number of enterprises in the city involves enterprises with the number of employees from 2 to 50 persons - 321 units with the total number of employees making 1,967 people. Wholesale and retail trade, repair of motor vehicles and motorcycles (24\%), construction $(12 \%)$ and industry $(12 \%)$ take the largest share in terms of economic activities among individuals and legal entities [21]. Therefore, the current situation for small and medium-sized businesses in the town is characterized by a decline, 
which contributes to the worsening of economic problems and increasing social destabilization.

The availability of financial resources and access to finance is nearly always a serious problem for new and small businesses. It is difficult to meet this demand at the local level; however, certain local actions to attract existing sources of funding can prove successful. The necessary information should include three main groups: representatives of the private sector (potential and actual businessmen); operating financial institutions and donor organizations; national sectoral ministries.

After discussing the town community's vision of Tokmak positioning, priority actions were identified [21]:

- attraction of foreign and domestic investments for creation and modernization of new and existing enterprises, as well as for the arrangement of public spaces, improvement of the state of social infrastructure and technical support of educational institutions, culture, health care;

- ensuring the socio-economic development of the territory on the basis of improving the mechanism of public-private partnership;

- participation in international projects and initiatives regarding energy conservation, energy efficiency and social cohesion;
- development of the infrastructure of residential districts of the town, provision of conditions for their residents' comfortable living, development of non-formal education, carrying out additional entertaining activities for youth and residents of the community.

The SWOT-analysis conducted allowed identifying potential options for solving the distinguished problems [21]:

- introducing educational programmes on setting up and pursuing their own business;

- facilitating access of start-ups to funding through international development programmes;

- conducting a public information campaign on occupational guidance of the youth;

- conducting communication activities with higher educational establishments in terms of job placement of graduates to get their first jobs in Tokmak;

- stimulating demand for labour resources - development of a more efficient model of training specialists who the town requires;

- forming a positive investment image;

- stimulating attraction of international technical support and grant resources to the territory. The primary goals and measures have been developed to overcome the depressiveness of Tokmak in Zaporizhzhia Region (Table 3).

Table 3

The system of goals and measures for overcoming depressiveness in Tokmak

\begin{tabular}{|c|c|c|}
\hline \multicolumn{3}{|c|}{ Primary goals of future development } \\
\hline Tokmak as an entrepreneur town & $\begin{array}{l}\text { Tokmak as a comfortable and safe } \\
\text { town }\end{array}$ & Tokmak as a responsible town \\
\hline \multicolumn{3}{|c|}{ within the framework of pursuing the goals, it is planned } \\
\hline $\begin{array}{l}\text { to enhance the development of dia- } \\
\text { logue and trust between the business } \\
\text { and government; to ensure the ease } \\
\text { of doing small and medium-sized } \\
\text { businesses in the town; to continue } \\
\text { to form the space of investment } \\
\text { partnerships and to establish devel- } \\
\text { opment of economic growth points }\end{array}$ & $\begin{array}{l}\text { to implement mechanisms of smart } \\
\text { city governance; to develop Tokmak } \\
\text { as a town of affordable quality ser- } \\
\text { vices, as well as a town for youth, } \\
\text { contemporary culture, art and sports }\end{array}$ & $\begin{array}{l}\text { to develop Tokmak as a town of } \\
\text { energy efficiency and independence } \\
\text { and as an eco-friendly place, and to } \\
\text { enhance the development of Tok- } \\
\text { mak as a town of social responsibil- } \\
\text { ity and social innovation }\end{array}$ \\
\hline
\end{tabular}

The Ministry of Communities and Territories of Ukraine has been designated as the state customer of the Target Program for Overcoming Depressiveness of Tokmak for 20182022, and its financing will be provided at the expense of both state and local budgets [22]. The volume of transfers per a Tokmak resident from the state budget is almost twice as high on average compared to cities in the oblast subordination. Regional budget grants are by 13.5 times larger than other local budgets. Currently, funds have already been allocated to support Tokmak's medicine. Moreover, the town is receiving about UAH 30 million from the envi- 
ronmental fund. Upon the town had received the official standing of the depressed territory, the mass media developed a clear association that the town of Tokmak is depressed. It should be emphasized, that in the short term this status forms a negative image of the town. Provided, that all necessary measures are taken within the framework of achieving the set goals, a positive effect is generated. Therefore, in the medium term perspective, obtaining the predicted results will help to rebrand the town, which will allow us to share the experience of overcoming depressiveness with other territorial communities.

Conclusions. In Ukraine, the majority of business entities in the entrepreneurial sector are represented by small and medium-sized enterprises, which corresponds to the global indicators; however, the conditions and effectiveness of their operation shows that there are unsolved problems. In the current context, administrative, legal and financial barriers hinder efficient state support for SMBs at the regional level, which is especially true in the context of the decentralization of the Ukrainian economy. Compared to big businesses, SMB functioning features certain advantages, which forms the socio-economic basis for the development of the region (territories, cities and towns) and provides for raising the living standards of the population. In Ukraine, financial support to SMBs is based on the legislative framework and is implemented in direct and indirect forms. Legislative acts define the legal, economic and organizational principles of the implementation of the state regional policy regarding the stimulation of the regional development and overcoming of the depressiveness of territories.

The analysis of scientific approaches to defining the features of depressed territories and distinguishing their varieties allowed determining the principles on which state support of depressed regions should be based: selectivity of state policy, validity of choosing objects, targeting, localization, legitimacy and obligatory accountability of the state support and its interconnection with the system of plans of socio-economic development of the region. It is established that the tools and institutional levers to overcome the depression of the territory should take into account the regional and local aspects, especially opportunities for entrepreneurial potential of SMBs.
In Ukraine, the town of Tokmak is recognized as the only town, which is depressed according to the established criteria and can receive the government support. As a result of the analysis of the local economic structure, it was revealed that over $66 \%$ of natural and legal persons are inactive. The current situation of small and medium-sized entrepreneurship in the town features a decline, which contributes to worsening economic problems and increasing social destabilization. Local authorities and members of the public have organized measures regarding the positioning of the city and determination of priority actions to overcome signs of depression. The conducted SWOT-analysis allowed identifying potential options for solving the problems stated and formulating the main goals and measures for overcoming depression based on the state financial support. Formation of institutional basis and creation of an efficient system of state financial support will allow providing conditions for implementation of entrepreneurial potential of SMBs for overcoming crisis phenomena, revitalizing the economy of the territory which has acquired signs of depression over the established period of time.

\section{Література}

1. Дорофієнко В. В. Напрями перетворення інституційного середовища у старопромислових регіонах на шляху підвищення їх конкурентоспроможності / В. В. Дорофієнко, В. В. Лоскутова // Вісник Хмельницького національного університету. Економічні науки. - 2014. - № 2(2). С. 134-137. - Режим доступу: http://nbuv.gov.ua/UJRN/Vchnu_ekon_2014_2(2)_28

2. Забезпечення підтримки та бізнесінкубування малого та середнього бізнесу в регіонах України в умовах трансформаційних перетворень / О. В. Якушева, В. С. Білозубенко. - В кн.: Трансформаційні перетворення регіональної економіки: [монографія] / За загальною редакцією Назаренка С. А. - К.: Кондор-Видавництво, 2016. 290 c. - C. 202-214.

3. Сімків Л. С. Тенденції розвитку малого підприємництва в Україні в умовах диспропорційності економічного зростання / Л. Є. Сімків, С. А. Побігун // Глобальні та національні проблеми економіки - Режим доступу: http://globalnational.in.ua/vipusk-3-2015/433-simkiv-1-e-pobigun-sa-tendentsiji-rozvitku-malogo-pidpriemnitstva-vukrajini-v-umovakh-disproportsijnosti-ekonomichnogozrostannya

4. Мареніченко В. В. Державне регулювання малого та середнього бізнесу у формуванні якісного регіонального розвитку / В. В. Мареніченко // Суспільно-політичний та соціокультурний розвиток 
південного регіону України: історичні традиції i сучасні тенденції : зб. статей для проведення I Всеукр. наук.-практ. конф. 21-22 трав. 2015 р. : Електронне наукове видання. - Одеса : ОРІДУ НАДУ, 2015. - С. 245-247.

5. Якушева О. В. Економічний розвиток i підтримка малого та середнього бізнесу на регіональному рівні: дис. ... канд. екон. наук: 08.00.05 / Якушева Оксана Вікторівна // Черкаський державний технологічний університет - Черкаси, $2017-288$ c.

6. Міца В. В. Малий бізнес як суб'єкт економічної системи регіону / В. В. Міца // Науковий вісник Ужгородського національного університету. Випуск 20. - Част. 2. - 2018. - С. 123-125.

7. Fedulova, I., Piatnytska, G., \& Lukashova, L. (2018). Small business in Ukraine: peculiarities and problems of development in the conditions of the fourth industrial revolution. Marketing and Management of Innovations, (3), 216-228. http://doi.org/10.21272/mmi.2018.3-19

8. Новицька О. В. Особливості підтримки малого та середнього бізнесу в системі сучасного регіонального менеджменту / О. В. Новицька // Вісник ЧДТУ: зб. наук. праць Черкаського державного технологічного університету. - Серія: Економічні науки. - Вип. 37. - Ч. II. - Черкаси: ЧДТУ, 2014. - С. 162-169.

9. Гончарук Т. В. Зарубіжний досвід розвитку підприємницьких структур та можливості його використання в Україні / Т.В. Гончарук // Ефективна економіка - 2017. - № 9. - Режим доступу:

http://www.economy.nayka.com.ua/?op=1\&z=5772

10. ЗУ «Про розвиток та державну підтримку малого і середнього підприємництва в Україні» Режим https://zakon.rada.gov.ua/laws/show/4618-17

11. 3У «Про державну допомогу суб’єктам господарювання» - Режим доступу: https://zakon.rada.gov.ua/laws/show/1555-18

12. ЗУ «Про стимулювання розвитку регіонів» Режим доступу:

https://zakon.rada.gov.ua/laws/show/2850-15

13. ЗУ «Про засади державної регіональної політики» - Режим доступу: https://zakon.rada.gov.ua/laws/show/156-19

14. Коломійчук В. С. Соціально-економічний розвиток адміністративного району в умовах перехідної економіки (підходи до вивчення, стратегії розвитку) / В. С. Коломійчук. - Тернопіль : Укрмедкнига, 2001. - 440 с.

15. Шевчук Я. В. Депресивні територіальні суспільні системи: критерії визначення та напрями санації / Я. В. Шевчук. - Львів, 2008. - 133 с.

16. Плотницька С. І. Проблеми ідентифікації депресивних територій України - Режим доступу: http://web.znu.edu.ua/herald/issues/2012/eco-4-

2012/195-200.pdf

17. Територія, на якій не живуть люди, не контролюється державою і стає ризикованою Режим доступу:

https://hromadske.radio/podcasts/terytoriya/terytoriya- na-yakiy-ne-zhyvut-lyudy-ne-kontrolyuyetsyaderzhavoyu-i-staye-ryzykovanoyu-tkachuk 4 вересня 2017

18. Можайкіна Н. В. Проблеми розвитку депресивних регіонів / Н. В. Можайкіна // Глобальні та національні проблеми економіки. - Миколаїв: Миколаївський національний університет ім. В.О. Сухомлинського. - 2016. - № 10. - С. 197-201.

19. Мареніченко В. В. Механізми реалізації державного регулювання якісного розвитку малого та середнього бізнесу в Україні: дис. ... канд. наук 3 держ. управ.: 25.00.02 / Мареніченко Валерій Валентинович // Дніпро: Дніпропетровський державний аграрноекономічний університет. - 2017. -255 c.

20. В облдержадміністрації знайшли причину депресивності Токмака 4.04.19 - Режим доступу: http://pro.tokmak.biz/content.php?id=601

21. План місцевого економічного розвитку міста Токмака до 2020 року - Режим доступу: http://www.meriatokmak.gov.ua/index.php/meri-zaekonomichne-zrostannya/3919-plan-mistsevogoekonomichnogo-rozvitku-mista-tokmaka-do-2020-roku

22. Урядовим комітетом схвалено концепцію програми подолання депресивності м. Токмак 11.05.2018 - Режим доступу: https://www.zoda.gov.ua/news/40808/uryadovimkomitetom-shvaleno-kontseptsiju-programi-podolannyadepresivnosti-m.-tokmak.html

\section{References}

1. Dorofiienko, V.V., \& Loskutova, V.V. (2014). Napriamy peretvorennia instytutsiinoho seredovyshcha u staropromyslovykh rehionakh na shliakhu pidvyshchennia yikh konkurentospromozhnosti. Visnyk Khmelnytskoho natsionalnoho universytetu. Ekonomichni nauky, 2(2), 134-137. Retrieved from http://nbuv.gov.ua/UJRN/Vchnu_ekon_2014_2(2)_28

2. Yakusheva, O.V., \& Bilozubenko, B.S. (2016). Zabezpechennia pidtrymky ta biznesinkubuvannia maloho ta serednoho biznesu $\mathrm{v}$ rehionakh Ukrainy v umovakh transformatsiinykh peretvoren. Nazarenko, S.A. (Ed.). Proceedings from Transformatsiyni peretvorennia rehionalnoii ekonomiky. Kyiv: KondorVydavnytstvo. (pp. 202-214).

3. Simkiv, L.Ye., \& Pobihun, S.A. (2015). Tendentsii rozvytku maloho pidpryiemnytstva $\mathrm{v}$ Ukraini $\mathrm{v}$ umovakh dysproportsiinosti ekonomichnoho zrostannia. Globalni ta Nationalni Problemy Economiky. Retrieved from http://global-national.in.ua/vipusk-3-2015/433simkiv-l-e-pobigun-s-a-tendentsiji-rozvitku-malogopidpriemnitstva-v-ukrajini-v-umovakhdisproportsijnosti-ekonomichnogo-zrostannya

4. Marenichenko, V.V. (2015). Derzhavne rehuliuvannia maloho ta serednoho biznesu u formuvanni yakisnoho rehionalnoho rozvytku «Proceedings from MIIM»'2015. 1-st Vseukrainska naukovo-praktychna konferentsiia. .Suspilno-politychnyi ta sotsiokulturnyi rozvytok pivdennoho rehionu Ukrainy: istorychni tradytsii i suchasni tendentsii: (pp. 245-247). Odesa: ORIDU NADU. 
5. Yakusheva, O.V. (2017). Якушева О.В. Ekonomichnyi rozvytok i pidtrymka maloho ta serednoho biznesu na rehionalnomu rivni. Cadidate's Thesis. Cherkasy: Cherkaskyy derzhavnyy Technolohichnyy Universytet.

6. Mitsa, VV. (2018). Malyi biznes yak subiekt ekonomichnoi systemy rehionu. Naukovyi visnyk Uzhhorodskoho natsionalnoho universytetu. Ser. «Economika», 20, 2, 123-125

7. Fedulova, I., Piatnytska, G., \& Lukashova, L. (2018). Small business in Ukraine: peculiarities and problems of development in the conditions of the fourth industrial revolution. Marketing and Management of Innovations, (3), 216-228. http://doi.org/10.21272/mmi.2018.3-19

8. Novytska, O.V. (2014). Osoblyvosti pidtrymky maloho ta serednoho biznesu $\mathrm{v}$ systemi suchasnoho rehionalnoho menedzhmentu. Proceedings from Visnyk ChDTU: zbirnyk naukovykh prats Cherkaskoho derzhavnoho tekhnolohichnoho universytetu, 37, II, 162169.

9. Honcharuk, T.V. (2017). Zarubizhnyi dosvid rozvytku pidpryiemnytskykh struktur ta mozhlyvosti yoho vykorystannia v Ukraini. Efektyvna ekonomika, (9), Retrieved from http://www.economy.nayka.com.ua/?op=1\&z=5772

10. Zakon Ukrainy «Pro rozvytok ta derzhavnu pidtrymku maloho $\mathrm{i}$ serednoho pidpryiemnytstva $\mathrm{v}$ Ukraini». Retrieved from https://zakon.rada.gov.ua/laws/show/4618-17

11. Zakon Ukrainy «Pro derzhavnu dopomohu subiektam hospodariuvannia». Retrieved from https://zakon.rada.gov.ua/laws/show/1555-18

12. Zakon Ukrainy «Pro stymuliuvannia rozvytku rehioniv»». Retrieved from https://zakon.rada.gov.ua/laws/show/2850-15

13. Zakon Ukrainy «Pro zasady derzhavnoii rehionalnoii polityky». Retrieved from https://zakon.rada.gov.ua/laws/show/156-19
14. Kolomiichuk, V.S. (2001). Sotsialnoekonomichnyi rozvytok administratyvnoho raionu $\mathrm{v}$ umovakh perekhidnoii ekonomiky (pidkhody do vyvchennia, stratehii rozvytku). Ternopil: Ukrmedknyha.

15. Shevchuk, Ya.V. (2008). Depresyvni terytorialni suspilni systemy: kryterii vyznachennia ta napriamy sanatsii. Lviv.

16. Plotnytska, S.I. (2012). Problemy identyfikatsii depresyvnykh terytorii Ukrainy. Retrieved from http://web.znu.edu.ua/herald/issues/2012/eco-42012/195-200.pdf

17. Terytoriia, na yakiy ne zhyvut liudy, ne kontroliuietsia derzhavoiu i staie ryzykovanoiu. Retrieved from https://hromadske.radio/podcasts/terytoriya/terytoriyana-yakiy-ne-zhyvut-lyudy-ne-kontrolyuyetsyaderzhavoyu-i-staye-ryzykovanoyu-tkachuk 4 вересня 2017.

18. Mozhaikina, N.V. (2016). Problemy rozvytku depresyvnykh rehioniv. Globalni ta Nationalni Problemy Ekonomiky, 10, 197-201.

19. Marenichenko, V.V. (2017). Mekhanizmy realizatsii derzhavnoho rehuliuvannia yakisnoho rozvytku maloho ta serednoho biznesu v Ukraini. Candidate's Thesis. Dnipro: Dnipro derzhavnyy Ahrarnoeconomichnyy Universytet,

20. V oblderzhadministratsii znayshly prychynu depresyvnosti Tokmaka. (2019). Retrieved from http://pro.tokmak.biz/content.php?id=601

21. Plan mistsevoho ekonomichnoho rozvytku mista Tokmaka do 2020 roku. Retrieved from http://www.meriatokmak.gov.ua/index.php/meri-zaekonomichne-zrostannya/3919-plan-mistsevogoekonomichnogo-rozvitku-mista-tokmaka-do-2020-roku

22. Uriadovym komitetom skhvaleno kontseptsiiu prohramy podolannia depresyvnosti m. Tokmak. (2018). Retrieved from https://www.zoda.gov.ua/news/40808/uryadovimkomitetom-shvaleno-kontseptsiju-programi-podolannyadepresivnosti-m.-tokmak.html

\section{ІНСТИТУЦІОНАЛЬНІ ВАЖЕЛІ ФІНАНСУВАННЯ МАЛОГО І СЕРЕДНЬОГО БІЗНЕСУ ЯК СКЛАДОВА РОЗВИТКУ ДЕПРЕСИВНИХ РЕГІОНІВ} Л. В. Тимоченко, к. е. н., доцент, О. В. Крилова, к. т. н., доцент, НТУ «Дніпровська політехніка»

Методологія дослідження. Результати отримані за рахунок застосування методів: критичного аналізу - при встановленні бар'єрів, що перешкоджають проведенню ефективної державної підтримки малого та середнього бізнесу на регіональному рівні; наукової абстракції - при визначенні переваг малого та середнього підприємництва у порівнянні з великим бізнесом щодо формування соціально-економічного підгрунтя розвитку регіону (території, міста); узагальнення - при встановленні інституціональних важелів подолання депресивності території.

Результати. Діагностовано, що переважну кількість суб'єктів господарювання сектору підприємництва в Україні представляють малі та середні підприємства, що відповідає світовим тенденціям. Однак результативність їх функціонування свідчить про наявність перешкод щодо використання переваг і потенційних можливостей. Показано, що фінансова державна підтримка малого та середнього бізнесу базується на законодавстві та здійснюється у прямій та опосередкованій формах. Реалізація державної регіональної політики щодо стиму- 
лювання розвитку регіонів і подолання депресивності територій визначається комплексом законодавчих актів та державних програм. Проаналізовано наукові підходи до визначення депресивних територій та формування їх різновидів, виокремлено основні принципи, на яких повинна грунтуватися державна підтримка цих регіонів.

Новизна. Встановлено, що інституціональні важелі та інструментарій подолання депресивності території повинні враховувати регіональний (місцевий) аспект щодо можливостей реалізації підприємницького потенціалу малого та середнього бізнесу за умови їх фінансової підтримки.

Практична значущість. Запропоновано орієнтири щодо формування програми подолання депресивності міста за умови взаємодії влади, бізнесу і громади, що дозволить досягти цілі розвитку малого та середнього бізнесу, забезпечити комфортні та безпечні умови для населення, формування міста соціальної відповідальності та соціальних інновацій.

Ключові слова: малий та середній бізнес, фінансовий розвиток, інституційна підтримка, регіональний рівень, депресивні території.

\section{ИНСТИТУЦИОНАЛЬНЫЕ РЫЧАГИ ФИНАНСИРОВАНИЯ МАЛОГО И СРЕДНЕГО БИЗНЕСА КАК СОСТАВЛЯЮЩАЯ РАЗВИТИЯ ДЕПРЕССИВНЫХ РЕГИОНОВ}

Л. В. Тимоченко, к. э. н., доцент, Е. В. Крилова, к. т. н., доцент, НТУ «Днепровская политехника»

Методология исследования. Результаты получены за счет применения методов: критического анализа - при установлении барьеров, препятствующих проведению эффективной государственной поддержки малого и среднего бизнеса на региональном уровне; научной абстракции - при определении преимуществ малого и среднего предпринимательства по сравнению с крупным бизнесом по формированию социально-экономической основы развития региона (территории, города); обобщения - при установлении институциональных рычагов преодоления депрессивности территории.

Результаты. Диагностировано, что подавляющее количество субъектов хозяйствования сектора предпринимательства в Украине представляют малые и средние предприятия, что соответствует мировым тенденциям. Однако результативность их функционирования свидетельствует о наличии препятствий по использованию преимуществ и потенциальных возможностей. Показано, что финансовая государственная поддержка малого и среднего бизнеса базируется на законодательстве и осуществляется в прямой и косвенной формах. Реализация государственной региональной политики по стимулированию развития регионов и преодолению депрессивности территорий определяется комплексом законодательных актов и государственных программ. Проанализированы научные подходы к определению депрессивных территорий и формированию их разновидностей, выделены основные принципы, на которых должна основываться государственная поддержка этих регионов.

Новизна. Установлено, что институциональные рычаги и инструментарий преодоления депрессивности территории должны учитывать региональный (местный) аспект возможностей реализации предпринимательского потенциала малого и среднего бизнеса при условии их финансовой поддержки.

Практическая значимость. Предложено ориентиры по формированию программы преодоления депрессивности города при условии взаимодействия власти, бизнеса и общества, что позволит достичь цели развития малого и среднего бизнеса, обеспечить комфортные и безопасные условия для населения, формирование города социальной ответственности и социальных инноваций.

Ключевые слюва: малый и средний бизнес, финансовое развитие, институциональная поддержка, региональный уровень, депрессивные территории.

Надійшла до редакиії 04.02.20 p. 